\title{
Preclinical Research into Basic Mechanisms of Radiation-Induced Heart Disease
}

\author{
M. Boerma and M. Hauer-Jensen \\ Division of Radiation Health, Department of Pharmaceutical Sciences, University of Arkansas for Medical Sciences, \\ 4301 West Markham, Slot 522-10, Little Rock, AR 72205, USA \\ Correspondence should be addressed to M. Boerma, mboerma@uams.edu
}

Received 15 June 2010; Accepted 4 September 2010

Academic Editor: Syed Wamique Yusuf

Copyright (๑) 2011 M. Boerma and M. Hauer-Jensen. This is an open access article distributed under the Creative Commons Attribution License, which permits unrestricted use, distribution, and reproduction in any medium, provided the original work is properly cited.

\begin{abstract}
Radiation-induced heart disease (RIHD) is a potentially severe side effect of radiotherapy of thoracic and chest wall tumors if all or part of the heart was included in the radiation field. RIHD presents clinically several years after irradiation and manifestations include accelerated atherosclerosis, pericardial and myocardial fibrosis, conduction abnormalities, and injury to cardiac valves. There is no method to prevent or reverse these injuries when the heart is exposed to ionizing radiation. This paper presents an overview of recent studies that address the role of microvascular injury, endothelial dysfunction, mast cells, and the renin angiotensin system in animal models of cardiac radiation injury. These insights into the basic mechanisms of RIHD may lead to the identification of targets for intervention in this late radiotherapy side effect.
\end{abstract}

\section{Introduction}

The worldwide number of long-term cancer survivors is growing fast with ongoing improvements in cancer therapies $[1,2]$. However, long-term cancer survivors may suffer from late side effects of cancer therapy. One of these late side effects is radiation-induced heart disease (RIHD), which may occur after radiotherapy of thoracic and chest wall tumors whenever all or part of the heart is situated in the radiation field. RIHD has been described to occur, for instance, among survivors of Hodgkin's Disease $[3,4]$ and breast cancer $[5,6]$. Radiotherapy planning has undergone many improvements over the last decades, with modalities such as Intensity-Modulated Radiation Therapy (IMRT), image-guided radiation therapy, and proton therapy, leading to reduced exposures of the heart. Nonetheless, recent studies indicate that problems may persist. For instance, patients with Hodgkin's Disease, lung cancer, and esophageal and proximal gastric cancer may still receive either a high dose of radiation to a small part of the heart or a lower dose to the whole heart [7-11]. In addition, although there is increasing use of concomitant therapies, the extent to which these therapies affect radiotherapy side effects such as RIHD is largely unknown.
Manifestations of RIHD include accelerated atherosclerosis, pericardial and myocardial fibrosis, conduction abnormalities, and injury to cardiac valves $[4,12]$. The disease is progressive and both incidence and severity increase with a higher radiation dose volume, younger age at the time of radiotherapy, a greater time elapsed since treatment, and concomitant use of cardiotoxic chemotherapeutic agents such as anthracyclines. Although RIHD is widely acknowledged as an impediment to quality of life for certain long-term cancer survivors, from a clinical perspective the only current way to reduce RIHD is through efforts to improve radiotherapy treatment planning, as other methods to prevent or reverse RIHD are not yet available. Hence, pre-clinical studies seek to unravel basic mechanisms of RIHD, with the ultimate goal to identify potential targets for intervention.

\section{Pre-Clinical Models of Radiation-Induced Heart Disease}

Pre-clinical animal models have long been used to study RIHD [13-18]. While transgenic mouse models are being used in investigations of radiation-accelerated atherosclerosis 
$[19,20]$, wild type rodents are usually not atherosclerosis prone. Hence, studies that use rodents to investigate radiation-induced coronary artery disease are limited in number $[21,22]$. On the other hand, many laboratory animals, including rodent, have been used successfully as models of radiation-induced cardiomyopathy [16, 23-27]. Common doses used in these pre-clinical models of localized heart irradiation are either a single dose between $5 \mathrm{~Gy}$ and $25 \mathrm{~Gy}$, or fractionated schedules of, for instance, 5 daily fractions of $9 \mathrm{~Gy}$. Some of the histopathological changes in pre-clinical models, such as myocardial degeneration and fibrosis, are also commonly described in human cases of RIHD, mainly after exposure to doses of $\sim 30$ Gy and above $[3,4,28-30]$. Although clinical and pre-clinical data on the cardiovascular effects of lower radiation doses are growing $[11,31]$, the focus of this review will be on myocardial injury and cardiac function changes after exposure to higher doses of radiation. Table 1 summarizes some of the main preclinical studies reviewed.

\section{Vascular Injury and Endothelial Dysfunction}

Previous paper indicate the important role of vascular injury and endothelial dysfunction (loss of thromboresistance and increased expression of adhesion molecules and cytokines) in the pathogenesis of normal tissue radiation injury $[42,43]$. Endothelial dysfunction may contribute to profibrotic and proinflammatory environments, which are common aspects of normal tissue radiation injury $[42,44]$. Although the role of endothelial dysfunction in RIHD has not been studied in detail, experimental RIHD is known to be associated with reduced myocardial capillary density $[32,33]$, focal loss of endothelial alkaline phosphatase $[14,34]$, and increased expression of von Willebrand factor [35]. Hence, microvascular injury and the resulting local ischemic injury are considered to be some of the underlying mechanisms of RIHD.

Radiation-induced vascular injury and endothelial dysfunction are mediated in part by Transforming Growth Factor- $\beta$ (TGF- $\beta$ ) $[45,46]$, a pluripotent growth factor that is part of many normal tissue radiation responses [47-49]. Previous studies have shown cardiac upregulation of TGF$\beta$ in rat models of RIHD after localized heart irradiation with $20 \mathrm{~Gy}$ or 5 fractions of $9 \mathrm{~Gy}$ [36-38]. A TGF- $\beta$ inducing compound was used to investigate the role of TGF$\beta$ in RIHD in the rat. Cardiac radiation fibrosis was more severe in animals that had been administered the TGF- $\beta$ inducing compound during the 6-month followup time after irradiation (unpublished data). Pre-clinical studies involving TGF- $\beta$ receptor inhibition are being undertaken.

\section{Mast Cells}

Mast cells, cells that belong to the hematopoietic myeloid lineage, reside in many organs and tissues including the heart. Although best known for their role in hypersensitivity reactions, mast cells are also intimately involved in wound healing and tissue remodeling [50-52]. Mast cells store and release a wide range of cellular mediators, both via degranulation and via constitutive pathways that do not involve degranulation [53]. Increased mast cell numbers are commonly found in coronary atherosclerosis, myocardial fibrosis [54, 55], and also in animal models of RIHD [40,56], where mast cell numbers correlate with myocardial radiation injury.

The development and maturation of mast cells depend on the c-kit receptor, which is specific for stem cell factor. Several mast cell deficient animal models, based on a mutation in the c-kit receptor or stem cell factor, are available [57-59]. Our laboratories have made use of a rat model that is homozygous for a 12-base deletion in the c-kit receptor gene $[60,61]$. Both mast cell-deficient rats and their mast cell-competent wild type litter mates were exposed to localized heart irradiation with a single dose of $18 \mathrm{~Gy}$. Although mast cell-deficiency was associated with reduced radiation-induced myocardial inflammation and degeneration, other manifestations of cardiac radiation injury such as myocardial fibrosis and ex vivo measures of myocardial stiffness were exacerbated in the absence of mast cells [41]. These studies suggest that mast cells, in contrast to what had been the prevailing assumption but similar to what has been found in some other cardiac disease models $[62,63]$, play a predominantly protective role in RIHD.

\section{Mast Cell Interactions}

Mast cells interact with many cellular and molecular systems in the heart. Mast cell-derived proteinases, for instance, have been shown to contribute to both the formation and degradation of endothelin-1 (ET-1) [64-68]. ET-1 is a 21amino acid peptide that was first discovered as a potent vasoconstrictor but also has proinflammatory and pro-fibrotic properties [69, 70]. The role of ET-1 in cardiovascular pathology has been studied extensively $[71,72]$. Both ET1 receptors, $\mathrm{ET}_{\mathrm{A}}$ and $\mathrm{ET}_{\mathrm{B}}$ are expressed by a wide variety of cell types in the heart $[70,73]$. Short-term upregulation of ET-1 and its receptors may serve as a mechanism to maintain cardiac function in certain cardiovascular diseases [74, 75]. Long-term up-regulation of the endothelin system, on the other hand, may have detrimental effects due to the vasopressor, prohypertrophic, and pro-fibrotic properties of ET-1 $[73,76]$.

Mast cells express the receptor $\mathrm{ET}_{\mathrm{A}}$, which upon activation by ET-1 induces mast cell degranulation [77], a pathway by which ET-1 may enhance the activity of matrix metalloproteinases (MMPs) in the heart [78, 79]. Dual inhibition of $\mathrm{ET}_{\mathrm{A}}$ and $\mathrm{ET}_{\mathrm{B}}$ prevented mast cell degranulation and the associated increase in cardiac MMP levels, interstitial collagen degradation, and ventricular dilatation in a rat model of chronic volume overload [80]. On the other hand, in a preliminary study of a rat model of RIHD, dual inhibition of $\mathrm{ET}_{\mathrm{A}}$ and $\mathrm{ET}_{\mathrm{B}}$ did not alter radiation-induced functional or structural cardiac changes [81]. Moreover, vascular injury seemed aggravated by selective $\mathrm{ET}_{\mathrm{A}}$ inhibition in a rat model of localized intestine irradiation [82]. Dosing of receptor antagonists and opposing cardiovascular effects of 
TABLE 1: Summary of pre-clinical studies into basic mechanisms of RIHD.

Main Observation or Study Outcome

References

Reduced myocardial capillary density, focal loss of endothelial alkaline phosphatase, and increased

expression of von Willebrand factor indicate vascular injury in rat models of RIHD.

$[14,32-35]$

Coronary artery disease has been observed after localized heart irradiation in hypertensive rats or rats on

a high-fat diet.

Increased myocardial levels of TGF- $\beta 1$, Ang II, and aldosterone have been found after localized heart

irradiation in rats.

ACE inhibitor captopril reduced myocardial fibrosis and prevented left ventricular capillary density loss after localized heart irradiation in rats.

Mast cell-deficient rats showed reduced radiation-induced myocardial inflammation and degeneration, but increased myocardial fibrosis when compared to mast cell-competent rats.

the $\mathrm{ET}_{\mathrm{A}}$ and $\mathrm{ET}_{\mathrm{B}}$,receptors $[83,84]$ warrant further studies to clarify the role of ET- 1 and its two receptors in RIHD.

Mast cells are one of the main cell types involved in neuroimmune interactions [85]. They are found in close proximity to nerve terminals or axons in many organs, including the heart $[86,87]$, and interact with nerves on the molecular level in many ways $[85,88,89]$. Mast cells express $\alpha$ - and $\beta$-adrenergic receptors [90, 91]. In normal rat myocardium, $\beta$-blockade is associated with increased mast cell degranulation and decreased collagen deposition [92]. Some sensory neuropeptides such as calcitonin generelated peptide (CGRP), substance $\mathrm{P}$, and neuropeptide $\mathrm{Y}$ are able to induce or enhance mast cell degranulation [93100] while others have been shown to inhibit mast cell degranulation [101, 102]. Mast cells, in turn, affect neuronal growth and function by producing nerve growth factor [103] and by activating proteinase-activated receptor- 2 on the surface of neurons $[104,105]$. Cardiac sensory nerves play a protective role in the heart via the release of nitric oxide and CGRP $[106,107]$. For instance, CGRP plays a protective role in myocardial injury such as from ischemia reperfusion and the cardiotoxic chemotherapeutic agent doxorubicin $[108,109]$. CGRP is a potent vasodilator but also has beneficial effects in the heart by local downregulation of tumor necrosis factor-alpha (TNF- $\alpha$ ) and upregulation of insulin-like growth factor-1 (IGF-1) [110, 111]. Interestingly, both downregulation of TNF- $\alpha$ and upregulation of IGF-1 are associated with reduced normal tissue radiation injury $[112,113]$. In line with this evidence, CGRP has been shown to protect in a rat model of radiation enteropathy [114]. Its role in RIHD has not yet been studied extensively.

\section{The Renin-Angiotensin System}

The role of the renin angiotensin system (RAS) in normal tissue radiation injury has been well defined $[115,116]$. Inhibitors of angiotensin-converting enzyme (ACE) and antagonists of angiotensin type 1 receptors reduce injury in animal models of localized kidney, lung, and brain irradiation [117-119]. Although the role of RAS in RIHD is less well defined, RAS mediators may be upregulated in the heart after irradiation [39]. However, while the ACE inhibitor captopril reduced radiation injury in kidney, lung, and skin of rats [119-121], captopril did not prevent cardiac function loss after localized heart irradiation with $20 \mathrm{~Gy}$ in a rat model. Captopril, on the other hand, did reduce myocardial fibrosis and prevented left ventricular capillary density loss after local heart irradiation. It is not known whether these effects were due to properties of captopril other than its inhibition of ACE [40].

Inhibition of $\mathrm{ACE}$ is considered to be cardioprotective in part by suppressing the breakdown of bradykinin by ACE [122]. Bradykinin, a small peptide hormone that is sometimes considered to aggravate cardiac disease with a significant inflammatory component such as myocardial infarction [123], is also known to mediate cardioprotection via induction of nitric oxide and prostacyclin [124-126]. Bradykinin is formed in the kallikrein-kinin system by proteolytic cleavage of both high- and low-molecular weight kininogen by kallikrein enzymes, but also by the mast cellderived enzyme tryptase $[127,128]$. Interestingly, the mast cell proteinases chymases are one of the main converters of angiotensin I into angiotensin II [129]. Mast cells seem to hereby provide a particularly large contribution to local extravascular generation of Ang II [130]. The roles of RAS and bradykinin in cardiac radiation injury and the potential influence of mast cells herein need further investigation.

\section{Conclusions}

Radiotherapy planning has undergone many improvements over the last decades, leading to improved targeting and reduced normal tissue radiation exposure. Nonetheless, some patients with Hodgkin's Disease, lung cancer, and esophageal and proximal gastric cancer may still receive either a high dose of radiation to a small part of the heart or a lower dose to the whole heart, which may lead to late manifestations of RIHD. Some of the basic mechanisms of RIHD have begun to emerge from recent pre-clinical studies and include the involvement of vascular injury, mast cells, and the RAS. Future studies will elucidate the significance of these mechanisms for clinical RIHD and their usefulness as targets for intervention in RIHD.

\section{Conflicts of Interest}

The authors have no potential conflicts of interest. 


\section{Acknowledgments}

Some of the presented work was supported by the National Institutes of Health (CA71382 and CA83719 to M. H. Jensen; CA148679 to M.Boerma), the American Cancer Society (RSG-10-125-01-CCE to MB), the American Heart Association (AHA 0425933 to MB), and the Lance Armstrong Foundation (LAF06SY4 to MB).

\section{References}

[1] A. Verdecchia, S. Guzzinati, S. Francisci et al., "Survival trends in European cancer patients diagnosed from 1988 to 1999," European Journal of Cancer, vol. 45, no. 6, pp. 10421066, 2009.

[2] G. Gatta, G. Zigon, R. Capocaccia et al., "Survival of European children and young adults with cancer diagnosed 1995-2002," European Journal of Cancer, vol. 45, no. 6, pp. 992-1005, 2009.

[3] M. J. Adams, S. R. Lipsitz, S. D. Colan et al., "Cardiovascular status in long-term survivors of Hodgkin's disease treated with chest radiotherapy," Journal of Clinical Oncology, vol. 22, no. 15, pp. 3139-3148, 2004.

[4] P. A. Heidenreich, S. L. Hancock, R. H. Vagelos, B. K. Lee, and I. Schnittger, "Diastolic dysfunction after mediastinal irradiation," American Heart Journal, vol. 150, no. 5, pp. 977982, 2005.

[5] Early Breast Cancer Trialists Collaborative Group, "Favourable and unfavourable effects on long-term survival of radiotherapy for early breast cancer: an overview of the randomised trials. Early Breast Cancer Trialists' Collaborative Group," The Lancet, vol. 355, pp. 1757-1770, 2000.

[6] M. J. Hooning, B. M. P. Aleman, A. J. M. van Rosmalen, M. A. Kuenen, J. G. M. Klijn, and F. E. van Leeuwen, "Causespecific mortality in long-term survivors of breast cancer: a 25-year follow-up study," International Journal of Radiation Oncology Biology Physics, vol. 64, no. 4, pp. 1081-1091, 2006.

[7] B. S. Chera, C. Rodriguez, C. G. Morris et al., "Dosimetric comparison of three different involved nodal irradiation techniques for stage II Hodgkin's lymphoma patients: conventional radiotherapy, intensity-modulated radiotherapy, and three-dimensional proton radiotherapy," International Journal of Radiation Oncology, Biology, Physics, vol. 75, no. 4, pp. 1173-1180, 2009.

[8] G. F. Tillman, T. Pawlicki, A. C. Koong, and K. A. Goodman, "Preoperative versus postoperative radiotherapy for locally advanced gastroesophageal junction and proximal gastric cancers: a comparison of normal tissue radiation doses," Diseases of the Esophagus, vol. 21, no. 5, pp. 437-444, 2008.

[9] D. C. Weber, N. Peguret, G. Dipasquale, and L. Cozzi, "Involved-node and involved-field volumetric modulated arc vs. fixed beam intensity-modulated radiotherapy for female patients with early-stage supra-diaphragmatic Hodgkin lymphoma: a comparative planning study," International Journal of Radiation Oncology Biology Physics, vol. 75, no. 5, pp. 1578-1586, 2009.

[10] W. C. Wu, C. L. Chan, Y. W. Wong, and J. P. Cuijpers, "A study on the influence of breathing phases in intensity-modulated radiotherapy of lung tumours using four-dimensional CT," British Journal of Radiology, vol. 83, no. 987, pp. 252-256, 2010.

[11] P. McGale and S. C. Darby, "Low doses of ionizing radiation and circulatory diseases: a systematic review of the published epidemiological evidence," Radiation Research, vol. 163, no. 3, pp. 247-257, 2005.

[12] M. J. Adams, P. H. Hardenbergh, L. S. Constine, and S. E. Lipshultz, "Radiation-associated cardiovascular disease," Critical Reviews in Oncology/Hematology, vol. 45, no. 1, pp. 55-75, 2003.

[13] S. L. McChesney, E. L. Gillette, and B. E. Powers, "Radiationinduced cardiomyopathy in the dog," Radiation Research, vol. 113, no. 1, pp. 120-132, 1988.

[14] S. Schultz-Hector and K. Balz, "Radiation-induced loss of endothelial alkaline phosphatase activity and development of myocardial degeneration: an ultrastructural study," Laboratory Investigation, vol. 71, no. 2, pp. 252-260, 1994.

[15] V. V. Yang, S. P. Stearner, and S. A. Tyler, "Radiation induced changes in the fine structure of the heart: comparison of fission neutrons and 60Co $\gamma$ rays in the mouse," Radiation Research, vol. 67, no. 2, pp. 344-360, 1976.

[16] J. R. Eltringham, L. F. Fajardo, and J. R. Stewart, "Adriamycin cardiomyopathy: enhanced cardiac damage in rabbits with combined drug and cardiac irradiation," Radiology, vol. 115, no. 2, pp. 471-472, 1975.

[17] O. Labudova, R. Hardmeier, H. Rink, and G. Lubec, "The transcription of the XRCC1 gene in the heart of radiationresistant and radiation-sensitive mice after ionizing irradiation," Pediatric Research, vol. 41, no. 3, pp. 435-439, 1997.

[18] S. Schultz-Hector and K.-R. Trott, "Radiation-induced cardiovascular diseases: is the epidemiologic evidence compatible with the radiobiologic data?" International Journal of Radiation Oncology Biology Physics, vol. 67, no. 1, pp. 10-18, 2007.

[19] S. Hoving, S. Heeneman, M. J. J. Gijbels et al., "Singledose and fractionated irradiation promote initiation and progression of atherosclerosis and induce an inflammatory plaque phenotype in ApoE(-/-) Mice," International Journal of Radiation Oncology Biology Physics, vol. 71, no. 3, pp. 848857, 2008.

[20] F. A. Stewart, S. Heeneman, J. Te Poele et al., "Ionizing radiation accelerates the development of atherosclerotic lesions in $\operatorname{ApoE}(-/-)$ mice and predisposes to an inflammatory plaque phenotype prone to hemorrhage," American Journal of Pathology, vol. 168, no. 2, pp. 649-658, 2006.

[21] S. Lauk and K.-R. Trott, "Radiation induced heart disease in hypertensive rats," International Journal of Radiation Oncology Biology Physics, vol. 14, no. 1, pp. 109-114, 1988.

[22] H. Gold, "Atherosclerosis in the rat. Effect of x-ray and a high fat diet," Proceedings of the Society for Experimental Biology and Medicine, vol. 111, pp. 593-595, 1962.

[23] T. Kitahara, K. Liu, K. Solanki, and K. R. Trott, "Functional and morphological damage after local heart irradiation and/or adriamycin in Wistar rats," Radiation Oncology Investigations, vol. 1, pp. 198-205, 1993.

[24] J. J. C. M. Krüse, C. Zurcher, E. G. Strootman et al., "Structural changes in the auricles of the rat heart after local ionizing irradiation," Radiotherapy and Oncology, vol. 58, no. 3, pp. 303-311, 2001.

[25] S. Lauk, Z. Kiszel, J. Buschmann, and K.-R. Trott, "Radiationinduced heart disease in rats," International Journal of Radiation Oncology Biology Physics, vol. 11, no. 4, pp. 801808, 1985.

[26] S. Hu, Y. Chen, L. Li et al., "Effects of adenovirus-mediated delivery of the human hepatocyte growth factor gene in experimental radiation-induced heart disease," International Journal of Radiation Oncology Biology Physics, vol. 75, no. 5, pp. 1537-1544, 2009. 
[27] L. F. Fajardo and J. R. Stewart, "Pathogenesis of radiation induced myocardial fibrosis," Laboratory Investigation, vol. 29, no. 2, pp. 244-257, 1973.

[28] J. P. Veinot and W. D. Edwards, "Pathology of radiationinduced heart disease: a surgical and autopsy study of 27 cases," Human Pathology, vol. 27, no. 8, pp. 766-773, 1996.

[29] F. C. Brosius III, B. F. Waller, and W. C. Roberts, "Radiation heart disease. Analysis of 16 young (aged 15 to 33 years) necropsy patients who received over 3,500 rads to the heart," American Journal of Medicine, vol. 70, no. 3, pp. 519-530, 1981.

[30] A. Hamza, P. A. Tunick, and I. Kronzon, "Echocardiographic manifestations of complications of radiation therapy," Echocardiography, vol. 26, no. 6, pp. 724-728, 2009.

[31] M. P. Little, E. J. Tawn, I. Tzoulaki et al., "A systematic review of epidemiological associations between low and moderate doses of ionizing radiation and late cardiovascular effects, and their possible mechanisms," Radiation Research, vol. 169, no. 1, pp. 99-109, 2008.

[32] L. F. Fajardo and J. R. Stewart, "Capillary injury preceding radiation-induced myocardial fibrosis," Radiology, vol. 101, no. 2, pp. 429-433, 1971.

[33] J. E. Baker, B. L. Fish, J. Su et al., "10 Gy total body irradiation increases risk of coronary sclerosis, degeneration of heart structure and function in a rat model," International Journal of Radiation Biology, vol. 85, no. 12, pp. 1089-1100, 2009.

[34] S. Lauk and K.-R. Trott, "Endothelial cell proliferation in the rat heart following local heart irradiation," International Journal of Radiation Biology, vol. 57, no. 5, pp. 1017-1030, 1990.

[35] M. Boerma, J. J. C. M. Kruse, M. M. Van Loenen et al., "Increased deposition of von willebrand factor in the rat heart after local Ionizing irradiation," Strahlentherapie und Onkologie, vol. 180, no. 2, pp. 109-116, 2004.

[36] M. Boerma, K. A. Roberto, and M. Hauer-Jensen, "Prevention and treatment of functional and structural radiation injury in the rat heart by pentoxifylline and alphatocopherol," International Journal of Radiation Oncology Biology Physics, vol. 72, no. 1, pp. 170-177, 2008.

[37] J. J. C. M. Krüse, C. I. Bart, A. Visser, and J. Wondergem, "Changes in transforming growth factor- $\beta$ (TGF- $\beta 1$ ), procollagen types I and III mRNA in the rat heart after irradiation," International Journal of Radiation Biology, vol. 75, no. 11, pp. 1429-1436, 1999.

[38] H. Liu, M. Xiong, Y.-F. Xia et al., "Studies on pentoxifylline and tocopherol combination for radiation-induced heart disease in rats," International Journal of Radiation Oncology Biology Physics, vol. 73, no. 5, pp. 1552-1559, 2009.

[39] R. Wu and Y. Zeng, "Does angiotensin II-aldosterone have a role in radiation-induced heart disease?" Medical Hypotheses, vol. 72, no. 3, pp. 263-266, 2009.

[40] R. Yarom, I. S. Harper, S. Wynchank et al., "Effect of captopril on changes in rats' hearts induced by long-term irradiation," Radiation Research, vol. 133, no. 2, pp. 187-197, 1993.

[41] M. Boerma, J. Wang, J. Wondergem et al., "Influence of mast cells on structural and functional manifestations of radiation-induced heart disease," Cancer Research, vol. 65, no. 8, pp. 3100-3107, 2005.

[42] J. Wang, M. Boerma, Q. Fu, and M. Hauer-Jensen, "Significance of endothelial dysfunction in the pathogenesis of early and delayed radiation enteropathy," World Journal of Gastroenterology, vol. 13, no. 22, pp. 3047-3055, 2007.

[43] J. W. Hopewell, W. Calvo, R. Jaenke, H. S. Reinhold, M. E. Robbins, and E. M. Whitehouse, "Microvasculature and radiation damage," Recent Results in Cancer Research, vol. 130, pp. 1-16, 1993.

[44] J. W. Denham and M. Hauer-Jensen, "The radiotherapeutic injury-a complex 'wound," Radiotherapy and Oncology, vol. 63, no. 2, pp. 129-145, 2002.

[45] J. J. C. M. Kruse, B. G. J. Floot, J. A. M. te Poele, N. S. Russell, and F. A. Stewart, "Radiation-nduced activation of TGF- $\beta$ signaling pathways in relation to vascular damage in mouse kidneys," Radiation Research, vol. 171, no. 2, pp. 188-197, 2009.

[46] M. Scharpfenecker, J. J. C. M. Kruse, D. Sprong, N. S. Russell, P. ten Dijke, and F. A. Stewart, "Ionizing radiation shifts the PAI-1/ID-1 balance and activates notch signaling in endothelial cells," International Journal of Radiation Oncology Biology Physics, vol. 73, no. 2, pp. 506-513, 2009.

[47] H. P. Rodemann, A. Binder, A. Burger, N. Guven, H. Loffler, and M. Bamberg, "The underlying cellular mechanism of fibrosis," Kidney International, Supplement, no. 54, pp. S32S36, 1996.

[48] K. K. Richter, C. W. Langberg, C.-C. Sung, and M. HauerJensen, "Association of transforming growth factor $\beta$ (TGF$\beta$ ) immunoreactivity with specific histopathologic lesions in subacute and chronic experimental radiation enteropathy," Radiotherapy and Oncology, vol. 39, no. 3, pp. 243-251, 1996.

[49] M. H. Barcellos-Hoff, "How do tissues respond to damage at the cellular level? The role of cytokines in irradiated tissues," Radiation Research, vol. 150, no. 5, pp. S109-S120, 1998.

[50] J. Kalesnikoff and S. J. Galli, "New developments in mast cell biology," Nature Immunology, vol. 9, no. 11, pp. 1215-1223, 2008.

[51] T. Gottwald, S. Coerper, M. Schäffer, G. Köveker, and R. H. Stead, "The mast cell-nerve axis in wound healing: a hypothesis," Wound Repair and Regeneration, vol. 6, no. 1, pp. 8-20, 1998.

[52] E. Crivellato, C. A. Beltrami, F. Mallardi, and D. Ribatti, “The mast cell: an active participant or an innocent bystander?" Histology and Histopathology, vol. 19, no. 1, pp. 259-270, 2004.

[53] S. J. Galli, J. Kalesnikoff, M. A. Grimbaldeston, A. M. Piliponsky, C. M. M. Williams, and M. Tsai, "Mast cells as "tunable" effector and immunoregulatory cells: recent advances," Annual Review of Immunology, vol. 23, pp. 749786, 2005.

[54] P. K. Koskinen, P. T. Kovanen, K. A. Lindstedt, and K. B. Lemström, "Mast cells in acute and chronic rejection of rat cardiac allografts-a major source of basic fibroblast growth factor," Transplantation, vol. 71, no. 12, pp. 1741-1747, 2001.

[55] Q.-Y. Li, A. Raza-Ahmad, M. A. MacAulay et al., "The relationship of mast cells and their secreted products to the volume of fibrosis in posttransplant hearts," Transplantation, vol. 53, no. 5, pp. 1047-1051, 1992.

[56] M. Boerma, C. Zurcher, I. Esveldt, C. I. Schutte-Bart, and J. Wondergem, "Histopathology of ventricles, coronary arteries and mast cell accumulation in transverse and longitudinal sections of the rat heart after irradiation," Oncology Reports, vol. 12, no. 2, pp. 213-219, 2004.

[57] E. N. Geissler and E. S. Russell, "Analysis of the hematopoietic effects of new dominant spotting (W) mutations of the mouse. II. Effects on mast cell development," Experimental Hematology, vol. 11, no. 6, pp. 461-466, 1983.

[58] Y. Kitamura and S. Go, "Decreased production of mast cells in S1/S1(d) anemic mice," Blood, vol. 53, no. 3, pp. 492-497, 1979. 
[59] Y. Kitamura, S. Go, and K. Hatanaka, "Decrease of mast cells in $\mathrm{W} / \mathrm{W}(\mathrm{V})$ mice and their increase by bone marrow transplantation," Blood, vol. 52, no. 2, pp. 447-452, 1978.

[60] T. Tsujimura, S. Hirota, S. Nomura et al., "Characterization of Ws mutant allele of rats: a 12-base deletion in tyrosine kinase domain of c-kit gene," Blood, vol. 78, no. 8, pp. 19421946, 1991.

[61] K. Horiguchi and T. Komuro, "Ultrastructural characterization of interstitial cells of Cajal in the rat small intestine using control and Ws/Ws mutant rats," Cell and Tissue Research, vol. 293, no. 2, pp. 277-284, 1998.

[62] M. Boerma, W. P. Fiser, G. Hoyt et al., "Influence of mast cells on outcome after heterotopic cardiac transplantation in rats," Transplant International, vol. 20, no. 3, pp. 256-265, 2007.

[63] J. Joseph, R. H. Kennedy, S. Devi, J. Wang, L. Joseph, and M. Hauer-Jensen, "Protective role of mast cells in homocysteine-induced cardiac remodeling," American Journal of Physiology-Heart and Circulatory Physiology, vol. 288, no. 5, pp. H2541-H2545, 2005.

[64] H. Ehrenreich, P. R. Burd, M. Rottem et al., "Endothelins belong to the assortment of mast cell-derived and mast cellbound cytokines," The New Biologist, vol. 4, no. 2, pp. 147156, 1992.

[65] L. A. Schneider, S. M. Schlenner, T. B. Feyerabend, M. Wunderlin, and H.-R. Rodewald, "Molecular mechanism of mast cell-mediated innate defense against endothelin and snake venom sarafotoxin," Journal of Experimental Medicine, vol. 204, no. 11, pp. 2629-2639, 2007.

[66] E. Simard, D. Jin, S. Takai, M. Miyazaki, I. Brochu, and P. D'Orléans-Juste, "Chymase-dependent conversion of big endothelin-1 in the mouse in vivo," Journal of Pharmacology and Experimental Therapeutics, vol. 328, no. 2, pp. 540-548, 2009.

[67] M. Maurer, J. Wedemeyer, M. Metz et al., "Mast cells promote homeostasis by limiting endothelin-1-induced toxicity," Nature, vol. 432, no. 7016, pp. 512-516, 2004.

[68] K. P. Metsärinne, P. Vehmaan-Kreula, P. T. Kovanen et al., "Activated mast cells increase the level of endothelin-1 mRNA in cocultured endothelial cells and degrade the secreted peptide," Arteriosclerosis, Thrombosis, and Vascular Biology, vol. 22, no. 2, pp. 268-273, 2002.

[69] L. L. Yang, S. Arab, P. Liu, D. J. Stewart, and M. Husain, "The role of endothelin-1 in myocarditis and inflammatory cardiomyopathy: old lessons and new insights," Canadian Journal of Physiology and Pharmacology, vol. 83, no. 1, pp. 47-62, 2005.

[70] R. M. Kedzierski and M. Yanagisawa, "Endothelin system: the double-edged sword in health and disease," Annual Review of Pharmacology and Toxicology, vol. 41, pp. 851-876, 2001.

[71] P. Cernacek, D. J. Stewart, J.-C. Monge, and J.-L. Rouleau, "The endothelin system and its role in acute myocardial infarction," Canadian Journal of Physiology and Pharmacology, vol. 81, no. 6, pp. 598-606, 2003.

[72] G. Ertl and J. Bauersachs, "Endothelin receptor antagonists in heart failure: current status and future directions," Drugs, vol. 64, no. 10, pp. 1029-1040, 2004.

[73] D. Giannessi, S. Del Ry, and R. L. Vitale, "The role of endothelins and their receptors in heart failure," Pharmacological Research, vol. 43, no. 2, pp. 111-126, 2001.

[74] S. Sakai, T. Miyauchi, T. Sakurai et al., "Endogenous endothelin-1 participates in the maintenance of cardiac function in rats with congestive heart failure: marked increase in endothelin-1 production in the failing heart," Circulation, vol. 93, no. 6, pp. 1214-1222, 1996.
[75] J. Piuhola, I. Szokodi, P. Kinnunen et al., "Endothelin-1 contributes to the Frank-Starling response in hypertrophic rat hearts," Hypertension, vol. 41, no. 1, pp. 93-98, 2003.

[76] T. Miyauchi and T. Masaki, "Pathophysiology of endothelin in the cardiovascular system," Annual Review of Physiology, vol. 61, pp. 391-415, 1999.

[77] H. Yamamura, T. Nabe, S. Kohno, and K. Ohata, "Endothelin-1 induces release of histamine and leukotriene C4 from mouse bone marrow-derived mast cells," European Journal of Pharmacology, vol. 257, no. 3, pp. 235-242, 1994.

[78] J. S. Janicki, G. L. Brower, J. D. Gardner et al., "Cardiac mast cell regulation of matrix metalloproteinase-related ventricular remodeling in chronic pressure or volume overload," Cardiovascular Research, vol. 69, no. 3, pp. 657-665, 2006.

[79] A. Lundequist, M. Åbrink, and G. Pejler, "Mast celldependent activation of pro matrix metalloprotease 2: a role for serglycin proteoglycan-dependent mast cell proteases," Biological Chemistry, vol. 387, no. 10-11, pp. 1513-1519, 2006.

[80] D. B. Murray, J. D. Gardner, G. L. Brower, and J. S. Janicki, "Effects of nonselective endothelin-1 receptor antagonism on cardiac mast cell-mediated ventricular remodeling in rats," American Journal of Physiology-Heart and Circulatory Physiology, vol. 294, no. 3, pp. H1251-H1257, 2008.

[81] M. Boerma, J. Wang, A. Kulkarni et al., "Influence of endothelin 1 receptor inhibition on functional, structural and molecular changes in the rat heart after irradiation," Radiation Research, vol. 170, no. 3, pp. 275-283, 2008.

[82] N. Jullien, K. Blirando, F. Milliat, J.-C. Sabourin, M. Benderitter, and A. François, "Up-regulation of endothelin type a receptor in human and rat radiation proctitish preclinical therapeutic approach with endothelin receptor blockade," International Journal of Radiation Oncology Biology Physics, vol. 74, no. 2, pp. 528-538, 2009.

[83] J. Piuhola, M. Mäkinen, I. Szokodi, and H. Ruskoaho, "Dual role of endothelin-1 via ETA and ETB receptors in regulation of cardiac contractile function in mice," American Journal of Physiology-Heart and Circulatory Physiology, vol. 285, no. 1, pp. H112-H118, 2003.

[84] M. Clozel, G. A. Gray, V. Breu, B.-M. Loffler, and R. Osterwalder, "The endothelin ET(B) receptor mediates both vasodilation and vasoconstriction in vivo," Biochemical and Biophysical Research Communications, vol. 186, no. 2, pp. 867-873, 1992.

[85] R. M. Williams, J. Bienenstock, and R. H. Stead, "Mast cells: the neuroimmune connection," Chemical Immunology, vol. 61, pp. 208-235, 1995.

[86] N. Arizono, S. Matsuda, T. Hattori, Y. Kojima, T. Maeda, and S. J. Galli, "Anatomical variation in mast cell nerve associations in the rat small intestine, heart, lung, and skin. Similarities of distances between neural processes and mast cells, eosinophils, or plasma cells in the jejunal lamina propria," Laboratory Investigation, vol. 62, no. 5, pp. 626-634, 1990.

[87] P. Laine, A. Naukkarinen, L. Heikkilä, A. Penttilä, and P. T. Kovanen, "Adventitial mast cells connect with sensory nerve fibers in atherosclerotic coronary arteries," Circulation, vol. 101, no. 14, pp. 1665-1669, 2000.

[88] S. D. Skaper, M. Pollock, and L. Facci, "Mast cells differentially express and release active high molecular weight neurotrophins," Molecular Brain Research, vol. 97, no. 2, pp. 177-185, 2001. 
[89] T. Ito, K.-I. Kawahara, K. Okamoto et al., "Proteolytic cleavage of high mobility group box 1 protein by thrombinthrombomodulin complexes," Arteriosclerosis, Thrombosis, and Vascular Biology, vol. 28, no. 10, pp. 1825-1830, 2008.

[90] W. Schulze and M. L. X. Fu, "Localization of $\alpha 1$ adrenoceptors in rat and human hearts by immunocytochemistry," Molecular and Cellular Biochemistry, vol. 163164, pp. 159-165, 1996.

[91] L. J. Kay and P. T. Peachell, "Mast cell $\beta 2$-adrenoceptors," Chemical Immunology and Allergy, vol. 87, pp. 145-153, 2005.

[92] A. Facoetti, S. Fallarini, S. Miserere et al., "Histochemical study of cardiac mast cells degranulation and collagen deposition: interaction with the cathecolaminergic system in the rat," European Journal of Histochemistry, vol. 50, no. 2, pp. 133-140, 2006.

[93] A.-M. Reynier-Rebuffel, P. Mathiau, J. Callebert et al., "Substance P, calcitonin gene-related peptide, and capsaicin release serotonin from cerebrovascular mast cells," American Journal of Physiology, vol. 267, no. 5, pp. R1421-R1429, 1994.

[94] G. H. Shen, L. Grundemar, Z. Zukowska-Grojec, R. Haakanson, and C. Wahlestedt, "C-terminal neuropeptide Y fragments are mast cell-dependent vasodepressor agents," European Journal of Pharmacology, vol. 204, no. 3, pp. 249-256, 1991.

[95] L. Grundemar, C. Wahlestedt, G. H. Shen, Z. ZukowskaGrojec, and R. Hakanson, "Biphasic blood pressure response to neuropeptide $\mathrm{Y}$ in anesthetized rats," European Journal of Pharmacology, vol. 179, no. 1-2, pp. 83-87, 1990.

[96] C. Arzubiaga, J. Morrow, L. J. Roberts II, and I. Biaggioni, "Neuropeptide Y, a putative cotransmitter in noradrenergic neurons, induces mast cell degranulation but not prostaglandin D2 release," Journal of Allergy and Clinical Immunology, vol. 87, pp. 88-93, 1991.

[97] M. Moriyama, T. Sato, H. Inoue et al., "The neuropeptide neuromedin $\mathrm{U}$ promotes inflammation by direct activation of mast cells," Journal of Experimental Medicine, vol. 202, no. 2, pp. 217-224, 2005.

[98] X.-Y. Hua, S. M. Back, and E. K. Tam, "Substance P enhances electrical field stimulation-induced mast cell degranulation in rat trachea," American Journal of Physiology, vol. 270, no. 6, pp. L985-L991, 1996.

[99] J. Janiszewski, J. Bienenstock, and M. G. Blennerhassett, "Picomolar doses of substance P trigger electrical responses in mast cells without degranulation," American Journal of Physiology, vol. 267, no. 1, pp. C138-C145, 1994.

[100] L. G. Morgan, S. P. Levick, T. G. Voloshenyuk et al., "A novel technique for isolating functional mast cells from the heart," Inflammation Research, vol. 57, no. 5, pp. 241-246, 2008.

[101] Y. Saavedra and P. Vergara, "Somatostatin inhibits intestinal mucosal mast cell degranulation in normal conditions and during mast cell hyperplasia," Regulatory Peptides, vol. 111, no. $1-3$, pp. $67-75,2003$.

[102] N. Tunçel, F. Töre, V. Sahintürk, D. Ak, and M. Tunçel, "Vasoactive intestinal peptide inhibits degranulation and changes granular content of mast cells: a potential therapeutic strategy in controlling septic shock," Peptides, vol. 21, no. 1, pp. 81-89, 2000.

[103] A. Leon, A. Buriani, R. Dal Toso et al., "Mast cells synthesize, store, and release nerve growth factor," Proceedings of the National Academy of Sciences of the United States of America, vol. 91, no. 9, pp. 3739-3743, 1994.

[104] C. U. Corvera, O. Déry, K. McConalogue et al., "Thrombin and mast cell tryptase regulate guinea-pig myenteric neurons through proteinase-activated receptors-1 and -2," Journal of Physiology, vol. 517, no. 3, pp. 741-756, 1999.

[105] T. Saito and N. W. Bunnett, "Protease-activated receptors: regulation of neuronal function," NeuroMolecular Medicine, vol. 7, no. 1-2, pp. 79-99, 2005.

[106] T. Csont, C. Csonka, P. Kovács, G. Jancsó, and P. Ferdinandy, "Capsaicin-sensitive sensory neurons regulate myocardial nitric oxide and cGMP signaling," European Journal of Pharmacology, vol. 476, no. 1-2, pp. 107-113, 2003.

[107] J. J. Preibisz, "Calcitonin gene-related peptide and regulation of human cardiovascular homeostasis," American Journal of Hypertension, vol. 6, no. 5 I, pp. 434-450, 1993.

[108] Y.-J. Li and J. Peng, "The cardioprotection of calcitonin generelated peptide-mediated preconditioning," European Journal of Pharmacology, vol. 442, no. 3, pp. 173-177, 2002.

[109] M. Katona, K. Boros, P. Sántha, P. Ferdinandy, M. Dux, and G. Jancsó, "Selective sensory denervation by capsaicin aggravates adriamycin-induced cardiomyopathy in rats," Naunyn-Schmiedeberg's Archives of Pharmacology, vol. 370, no. 6, pp. 436-443, 2004.

[110] N. Harada and K. Okajima, "Effect of capsaicin on plasma and tissue levels of insulin-like growth factor-I in spontaneously hypertensive rats," Growth Hormone and IGF Research, vol. 18, no. 1, pp. 75-81, 2008.

[111] J. Peng, J. Xiao, F. Ye, H.-W. Deng, and Y.-J. Li, "Inhibition of cardiac tumor necrosis factor- $\alpha$ production by calcitonin gene-related peptide-mediated ischemic preconditioning in isolated rat hearts," European Journal of Pharmacology, vol. 407, no. 3, pp. 303-308, 2000.

[112] K. H. Limesand, S. Said, and S. M. Anderson, "Suppression of radiation-induced salivary gland dysfunction by IGF-1," PLoS ONE, vol. 4, no. 3, Article ID e4663, 2009.

[113] X. W. Huang, J. Yang, A. F. Dragovic, H. Zhang, T. S. Lawrence, and M. Zhang, "Antisense oligonucleotide inhibition of tumor necrosis factor receptor 1 protects the liver from radiation-induced apoptosis," Clinical Cancer Research, vol. 12, no. 9, pp. 2849-2855, 2006.

[114] J. Wang, X. Qiu, A. Kulkarni, and M. Hauer-Jensen, "Calcitonin gene-related peptide and substance $\mathrm{P}$ regulate the intestinal radiation response," Clinical Cancer Research, vol. 12, no. 13, pp. 4112-4118, 2006.

[115] M. E. Robbins and D. I. Diz, "Pathogenic role of the reninangiotensin system in modulating radiation-induced late effects," International Journal of Radiation Oncology Biology Physics, vol. 64, no. 1, pp. 6-12, 2006.

[116] J. E. Moulder, B. L. Fish, and E. P. Cohen, "Treatment of radiation nephropathy with ACE inhibitors and aII type1 and type-2 receptor antagonists," Current Pharmaceutical Design, vol. 13, no. 13, pp. 1317-1325, 2007.

[117] M. E. Robbins, V. Payne, E. Tommasi et al., "The AT1 receptor antagonist, L-158,809, prevents or ameliorates fractionated whole-brain irradiationinduced cognitive impairment," International Journal of Radiation Oncology Biology Physics, vol. 73, no. 2, pp. 499-505, 2009.

[118] A. Molteni, J. E. Moulder, E. F. Cohen et al., "Control of radiation-induced pneumopathy and lung fibrosis by angiotensin-converting enzyme inhibitors and an angiotensin II type 1 receptor blocker," International Journal of Radiation Biology, vol. 76, no. 4, pp. 523-532, 2000.

[119] J. E. Moulder, B. L. Fish, and E. P. Cohen, "Angiotensin II receptor antagonists in the treatment and prevention of radiation nephropathy," International Journal of Radiation Biology, vol. 73, no. 4, pp. 415-421, 1998. 
[120] A. Molteni, L. F. Wolfe, W. F. Ward et al., "Effect of an angiotensin II receptor blocker and two angiotensin converting enzyme inhibitors on transforming growth factor- $\beta$ (TGF- $\beta$ ) and $\alpha$-Actomyosin ( $\alpha$ SMA), important mediators of radiation-induced pneumopathy and lung fibrosis," Current Pharmaceutical Design, vol. 13, no. 13, pp. 1307-1316, 2007.

[121] W. F. Ward, A. Molteni, C. Ts'ao, and J. M. Hinz, "The effect of Captopril on benign and malignant reactions in irradiated rat skin," British Journal of Radiology, vol. 63, no. 749, pp. 349-354, 1990.

[122] I. Fleming, "Signaling by the angiotensin-converting enzyme," Circulation Research, vol. 98, no. 1, pp. 887-896, 2006.

[123] M. K. Koike, C. De Carvalho Frimm, and M. De Lourdes Higuchi, "Bradykinin B2 receptor antagonism attenuates inflammation, mast cell infiltration and fibrosis in remote myocardium after infarction in rats," Clinical and Experimental Pharmacology and Physiology, vol. 32, no. 12, pp. 11311136, 2005.

[124] N. N. Kim, S. Villegas, S. R. Summerour, and F. J. Villarreal, "Regulation of cardiac fibroblast extracellular matrix production by bradykinin and nitric oxide," Journal of Molecular and Cellular Cardiology, vol. 31, no. 2, pp. 457-466, 1999.

[125] Y. Tanaka, M. Nagai, T. Date et al., "Effects of bradykinin on cardiovascular remodeling in renovascular hypertensive rats," Hypertension Research, vol. 27, no. 11, pp. 865-875, 2004.

[126] H. Yin, L. Chao, and J. Chao, "Nitric oxide mediates cardiac protection of tissue kallikrein by reducing inflammation and ventricular remodeling after myocardial ischemia/reperfusion," Life Sciences, vol. 82, no. 3-4, pp. 156165,2008 .

[127] T. Imamura, A. Dubin, W. Moore, R. Tanaka, and J. Travis, "Induction of vascular permeability enhancement by human tryptase: dependence on activation of prekallikrein and direct release of bradykinin from kininogens," Laboratory Investigation, vol. 74, no. 5, pp. 861-870, 1996.

[128] L. G. Coffman, J. C. Brown, D. A. Johnson et al., "Cleavage of high-molecular-weight kininogen by elastase and tryptase is inhibited by ferritin," American Journal of Physiology-Lung Cellular and Molecular Physiology, vol. 294, no. 3, pp. L505L515, 2008.

[129] M. Miyazaki and S. Takai, "Tissue angiotensin II generating system by angiotensin-converting enzyme and chymase," Journal of Pharmacological Sciences, vol. 100, no. 5, pp. 391397, 2006.

[130] A. Lundequist, E. Tchougounova, M. Åbrink, and G. Pejler, "Cooperation between mast cell carboxypeptidase A and the chymase mouse mast cell protease 4 in the formation and degradation of angiotensin II," Journal of Biological Chemistry, vol. 279, no. 31, pp. 32339-32344, 2004. 


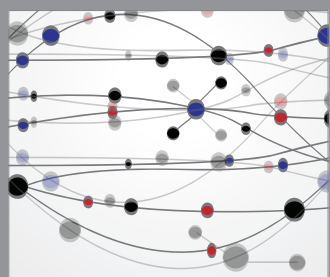

The Scientific World Journal
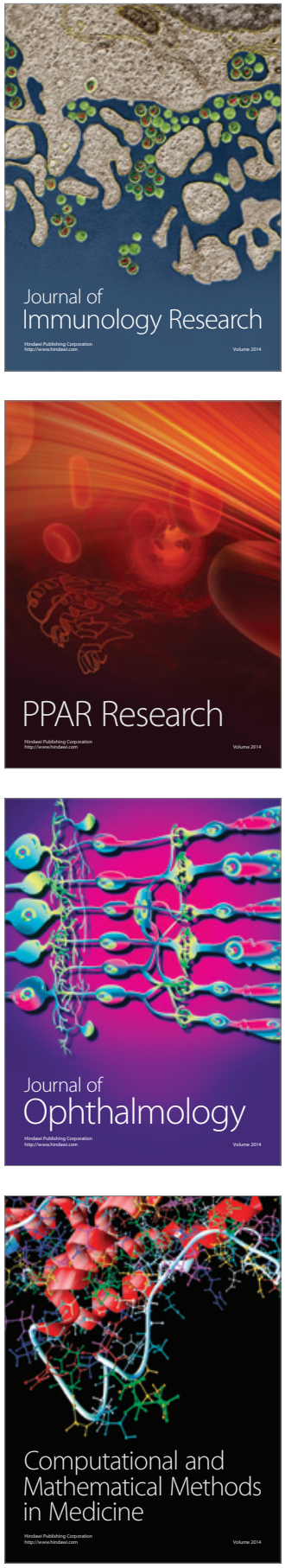

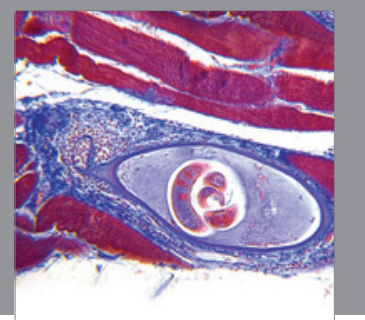

Gastroenterology

Research and Practice
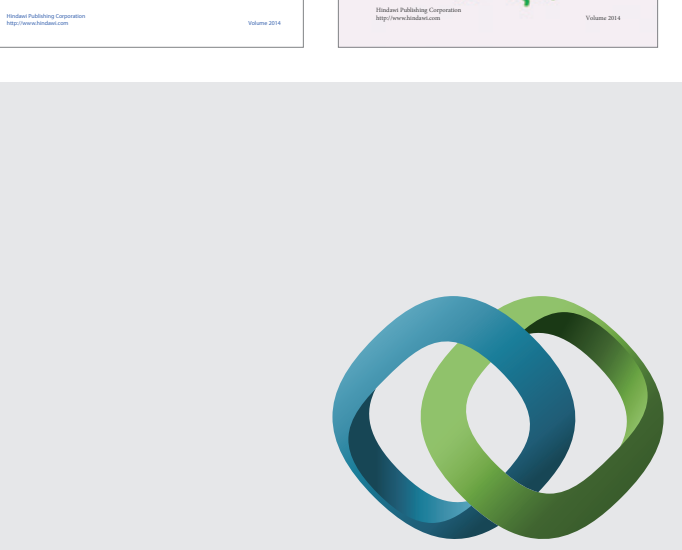

\section{Hindawi}

Submit your manuscripts at

http://www.hindawi.com
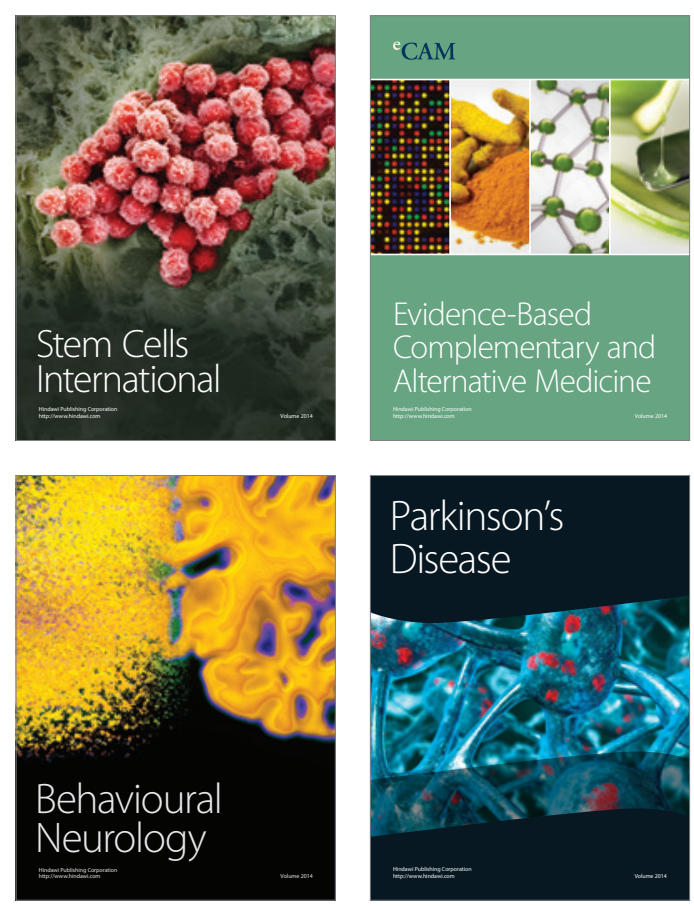

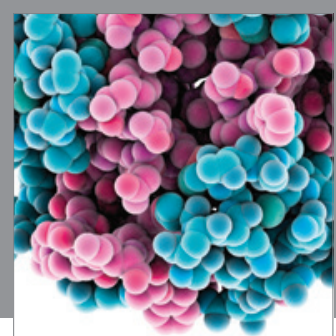

Journal of
Diabetes Research

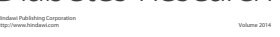

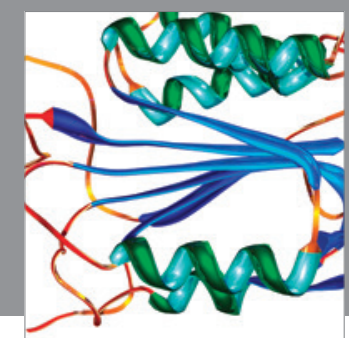

Disease Markers
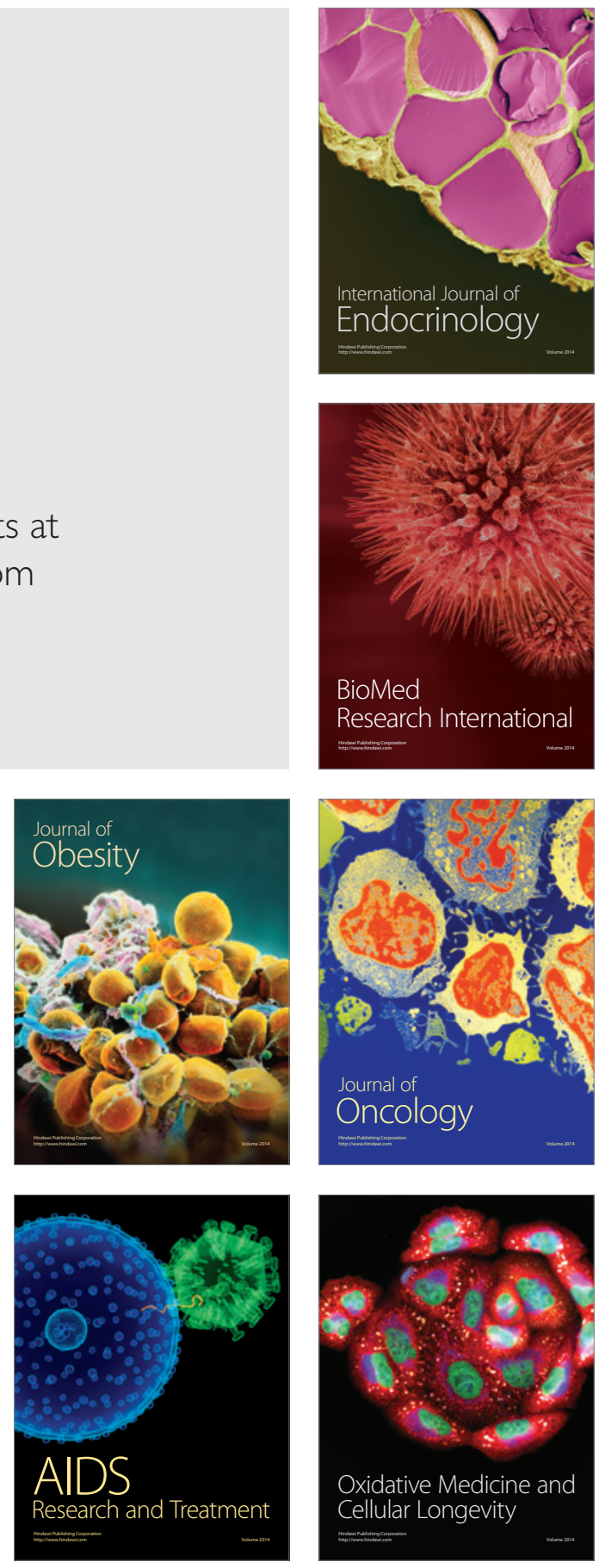